\title{
Areas of modernization of preparation of future elementary school teachers in the countries of the European community
}

\author{
Áreas de modernização de preparação de futuros professores do \\ primeiro escolar nos países da comunidade europeia
}

\section{Áreas de modernización de la preparación de futuros profesores de escuela primaria en los países de la comunidad europea}

\author{
Zinovii Onyshkiv $^{1}$ (D), Yaroslava Kodliuk ${ }^{1}$ (D), Tetiana Lesina² ${ }^{\text {iD }}$, \\ Olena Malyna ${ }^{3}$ iD, Nadya Kichuk ${ }^{2}$ iD
}

\footnotetext{
${ }^{1}$ Ternopil Volodymyr Hnatiuk National Pedagogical University, Ternopil, Ukraine.

${ }^{2}$ Izmail State University of Humanities, Izmail, Ukraine.

${ }^{3}$ Zaporizhzhia National University, Zaporizhzhia, Ukraine.
}

\section{Corresponding author:}

Zinovii Onyshkiv

Email: onyshkivz54@ukr.net

How to cite: Onyshkiv, Z., Kodliuk, Y., Lesina, T., Malyna, O., \& Kichuk, N. (2021). Areas of modernization of preparation of future elementary school teachers in the countries of the European community. Revista Tempos e Espaços em Educação, 14(33), e15615. http://dx.doi.org/10.20952/revtee.v14i33.15615

\begin{abstract}
The article describes the directions of modernization of preparation of future elementary school teachers in the countries of the European Community, analyzes the normative documents, which reflect the basic requirements for professional pedagogical training. The ways of standardization of elementary school teachers training in pedagogical colleges at the pedagogical faculties of universities are distinguished: national standard of qualified teacher, national curriculum, criteria for professional and pedagogical readiness of the university graduates are defined and reflected in their qualification characteristics. Psychological-pedagogical component, which includes a cycle of psycho-pedagogical disciplines, is recognized as a priority in the professional training of teachers. A characteristic feature of professional pedagogical training is two-phase - academic and practical training, two-stage system of training: at the level of bachelor and master. The tendency to reduce the number of pedagogical colleges and their accession to universities is indicated. The integration of pedagogical education of the countries of the European Community is characterized and the principles of development of the European educational space are named. Four paradigms that coexist in the educational systems of European countries are distinguished: academic-traditional, technological, individual, and research-oriented. The role of pedagogical practice in the system of preparation of future primary school teachers in the countries of Europe is characterized, its types and duration are distinguished.
\end{abstract}


Keywords: Education. Individualization. Polyparadigmality. Teaching.

\section{RESUMO}

O artigo descreve os rumos da modernização da formação dos futuros professores do ensino fundamental nos países da Comunidade Européia, analisa os documentos normativos, que refletem os requisitos básicos para a formação profissional pedagógica. São diferenciadas as formas de padronização da formação de professores do ensino fundamental nas faculdades pedagógicas das faculdades pedagógicas das universidades: padrão nacional de professor qualificado, currículo nacional, critérios de prontidão profissional e pedagógica dos graduados universitários são definidos e refletidos em suas características de qualificação. A componente psicológico-pedagógica, que inclui um ciclo de disciplinas psicopedagógicas, é reconhecida como prioritária na formação profissional dos professores. Uma característica da formação profissional pedagógica é a formação em duas fases - formação acadêmica e prática, sistema de formação em duas fases: a nível de licenciatura e mestrado. É indicada a tendência de redução do número de faculdades pedagógicas e sua adesão às universidades. A integração da educação pedagógica dos países da Comunidade Européia é caracterizada e os princípios de desenvolvimento do espaço educacional europeu são nomeados. Distinguem-se quatro paradigmas que coexistem nos sistemas educacionais dos países europeus: acadêmico-tradicional, tecnológico, individual e voltado para a pesquisa. É caracterizado o papel da prática pedagógica no sistema de preparação dos futuros professores do ensino primário nos países da Europa, distinguindo-se os seus tipos e duração.

Palavras-chave: Educação. Ensino. Individualização. Poliparadigmalidade.

\section{RESUMEN}

El artículo describe las direcciones de modernización de la preparación de los futuros maestros de escuela primaria en los países de la Comunidad Europea, analiza los documentos normativos, que reflejan los requisitos básicos para la formación pedagógica profesional. Se distinguen las formas de estandarización de la formación de maestros de escuela primaria en colegios pedagógicos en las facultades pedagógicas de las universidades: estándar nacional de maestro calificado, plan de estudios nacional, los criterios para la preparación profesional y pedagógica de los graduados universitarios se definen y reflejan en sus características de calificación. El componente psicológicopedagógico, que incluye un ciclo de disciplinas psicopedagógicas, es reconocido como una prioridad en la formación profesional de los docentes. Un rasgo característico de la formación pedagógica profesional es de dos fases: formación académica y práctica, sistema de formación de dos etapas: a nivel de licenciatura y maestría. Se indica la tendencia a reducir el número de escuelas superiores pedagógicas y su adhesión a las universidades. Se caracteriza la integración de la educación pedagógica de los países de la Comunidad Europea y se nombran los principios de desarrollo del espacio educativo europeo. Se distinguen cuatro paradigmas que conviven en los sistemas educativos de los países europeos: académico-tradicional, tecnológico, individual y orientado a la investigación. Se caracteriza el papel de la práctica pedagógica en el sistema de preparación de los futuros profesores de primaria en los países de Europa, se distinguen sus tipos y duración.

Palabras clave: Educación. Individualización de la docencia. Poliparadigmalida.

\section{INTRODUCTION}

In the conditions of globalization of economy, science and culture, the solution of many problems of the present is impossible without studying the world experience in different spheres of public life, including in the sphere of education. In this context, the experience of the countries of the world concerning the training of future primary school teachers is of great interest.

The Pedagogical Constitution of Europe states: «... the future of every nation, country and community of nations depends to a large extent on the qualitative training of future educators. 
Currently, European countries are offering a variety of training models in content and form. The unifying processes that take place in modern Europe lead to the search for common ground for the complex architecture of teacher training" (Association of Rectors of Pedagogical Universities in Europe, 2019).

The main requirements for professional pedagogical training are reflected in the UNESCO Recommendations on the status of teaching staff at higher education institutions (1997), the Lisbon Accords (1997) on the recognition of the Bologna Process for the creation of a European space in higher education, International Standard Classification of Education - 2011) (Association of Rectors of Pedagogical Universities in Europe, 2019).

In the highly developed countries of the globalizing world, great importance is attached to the teacher's professional preparation for pedagogical activity, since the teacher was, is, and remains the main actor responsible for fulfilling the educational tasks. Therefore, each country is interested in training such teachers who would be well versed in scientific theory and able to use modern teaching methods.

Mushynska (2018), Drobnic, (2019), Margvelashvili and Kostava (2020) indicate that in the world educational practice there have been some directions in the preparation of future professionals for professional activity. Identification and knowledge of them will help to modernize the system of training of pedagogical personnel (Arsawan et al., 2020; Bantash et al., 2020), improve the quality and continuity of pedagogical education, and enhance the professionalism of teachers.

\section{METHODOLOGY}

The purpose of the article is to identify and characterize the main areas of modernization of the training of future elementary school teachers in the countries of the European Community and to determine the possibilities of using such experience in national pedagogical universities.

The methods of analysis and synthesis are used in the European community to study the problem of training future teachers - to single out specific features of training future teachers and identify common features of this training, to search the main directions of modernization of this training in the pedagogical literature; quantitative comparative problem analysis method to conduct a study of the legal framework, determine the educational and qualification requirements for the content, organizational forms and methods of professional training of future teachers in the European community.

\section{RESULTS}

The analysis of scientific researches of national and foreign teachers on the preparation of elementary school teachers gives an opportunity to distinguish the following main areas of modernization of the preparation of future teachers: Standardization of future teachers' pedagogical training, Integration of pedagogical education of EU countries into the pan-European educational space, and Individualization of teaching of future teachers.

\section{Standardization of future teachers' pedagogical training}

In most countries of the European Community, elementary school teachers are trained in secondary or semi-higher pedagogical educational institutions (pedagogical college, normal school, pedagogical school), which are of two types depending on the length of study: a) four years based on incomplete high school (Denmark, Italy, Norway, etc.) and two years based on full-time secondary education (England, Germany, etc.). In the modern world, there is a tendency to extend the length of study in higher education pedagogical colleges to 3 or 4 years. In some countries, such colleges, with the length of study of 4 years, become pedagogical faculties of universities or their branches (Sbruieva, 1999). 
The main areas of standardization of pedagogical education in England are presented in the National Qualified Teacher Standard. The National Qualified Teacher Standard of 2007 includes three sections: professional attributes, professional knowledge and understanding, professional skills that include professional skills such as broad erudition, diverse spiritual interests, creativity, etc., as well as knowledge of fundamental disciplines, skills and ability to manage pedagogical activities, create a favorable atmosphere in the educational process. The Qualified Teacher Standard includes the content of the National Program and the forms of teacher training in basic subjects. The national curriculum for basic teacher training includes curricula, programs, forms and methods of teaching and learning, teaching and learning resources (Polishchuk, 2011).

A key provision of the standardization process in the United Kingdom is the definition of criteria for the professional and pedagogical readiness of a graduate, that is of a young teacher (competences) recorded in the qualification characteristic. Another key provision of the reform is that the school should play the role of a high school partner in the system of vocational training. This means that the university and the school are jointly responsible for developing and implementing «teacher training programs; structure and content of pedagogical practice; teaching methods of specialization and school curriculum; methods of testing students' knowledge; methods of evaluation of students' practical work; joint verification of the final result of vocational training; training programs» (Pukhovska, 2007).

A significant achievement in the professional training of French teachers is the development and implementation of qualification standards. Bachelor's degree preparation includes 3 years of university education and 2 years of university teacher training institutes. In the first year of study professional-theoretical training in the field of special and pedagogical disciplines is carried out, and in the second year - purely practical training based on the obtained knowledge. Future educators should acquire a certain amount of knowledge within the defined standards of professional competence.

The content of teacher training includes a combination of general, specialized and theoretical disciplines of the psychological and pedagogical component and the use of acquired knowledge in practice. Psychological-pedagogical component is a priority in the process of modernization of the content of vocational training (Lashchykhina, 2009).

Vocational and pedagogical training includes a cycle of psycho-pedagogical disciplines: philosophy of education, general pedagogy, history of pedagogy and social aspects of education, psychology. For elementary school teachers, in addition to these disciplines, there is also an integrated course "Maternal School», which covers the psycho-pedagogical problems of the preschool link in the education system, as well as the course «Training of immigrants" children».

"The theoretical course "Maternal School» and pedagogical practice that students, i.e. future teachers have in preschool institutions is a characteristic feature of professional and pedagogical training of French elementary school teachers» (Pukhovska, 2007). This course involves mastering by future teachers the knowledge of the age characteristics of preschool children, the specifics of mother school, including the method of educational work, the ability to determine the level of development of preschoolers, in particular, their readiness to study in school.

In Germany, for a long time primary school teachers were trained at a higher pedagogical school with the length of study of six semesters (in some countries -8 semesters). Formally, higher pedagogical schools are equated with higher educational establishments, but in fact they remained "second-class» universities. In today's context, the process of joining pedagogical higher education institutions to universities continues, which has led to the emergence of a variety of organizational models of teacher training.

The most typical form of accession, as noted by L. P. Pukhovska, was the creation of the Faculty of Education. However, under decentralized management of the education system, each university addresses this problem in its own way. 
However, the two-phase preparation remains unchanged: the first phase is academic, the second is practical. The first phase covers general science, subject-specific and minor psychopedagogical training, and includes school practice ( 8 weeks). The second phase of future teachers' professional training consists of teaching at a tutor-led school in a general seminar, teaching in seminars on the methods of teaching the two main subjects, that is, combining practical training with the study of pedagogical disciplines. This period is called the preparatory service, which ends with the second exam at the university.

"Among the main shortcomings of the second phase of teacher training for practical work at school, according to L. P. Pukhovska, is its autonomy and separation from the university, which creates a gap between theoretical and practical training. And the fact that the preparatory service is subordinate to the local education authorities practically involves the possibility of the university to control this phase of teacher training, thus depriving this work of scientific adjustment» (Pukhovska, 2007).

Content and forms of basic teacher training are being updated in Germany. In the process of developing the base of theoretical and professional knowledge of the future teacher, fundamentalization of teacher training and the growth of the dual function of pedagogical knowledge are observed. The authors of humanistic pedagogy pay more attention to the formation of children's own experience, the environment, social interaction in the educational process, that is, a turn to pedagogy of everyday life is carried out.

In Norway, there are two approaches to teacher training: teacher training in colleges (4 years of study); teacher training at universities.

Pedagogical colleges and colleges of university level provide pedagogical training in two specialties: elementary school teacher (2-3 years) and middle school teacher (3-4 years).

Teacher training in this country is based on the recommendations provided in the National Curriculum: a three-year program for kindergarten and elementary school teachers; a four-year program for the differentiated training of elementary and basic school teachers; four-year program for the general teacher.

In Denmark, the Ministry of Education has prepared a special credit transfer program for the training of future teachers. It is designed for 4 years and includes compulsory and optional subjects. The following are offered as basic or main subjects: humanities - Danish, English, French, German, History, Christianity / Religious Studies, Social Sciences; sciences - biology, physics / chemistry, geography, mathematics, natural sciences, technology; practical / aesthetic sciences - fine arts, domestic economics, design, sports, music, the art of working with metal and wood.

For compulsory study, a student must select subjects from at least two subject cycles. Each core subject must be studied for at least four semesters (Roliak, 2020).

In Poland, a new standard of teacher training has been adopted, so from the 2012-2013 academic year vocational training is modular. The essence of it is students are to study the following three modules: the first module involves a certain direction of preparation; the second module includes pedagogical and psychological preparation (different stages of education are taken into account - kindergarten, elementary school, high school, gymnasium, as well as the formation of skills for working with children with special needs); the third module involves the study of didactics. In addition to these core modules, there are modules four and five, which provide training in special pedagogy (Luchaninova et al., 2019).

Vocational training of future teachers in Hungary is carried out according to the scheme $3+$ 2 years of study (three years is the length of preparation of bachelors and another two years for master's training) (Borkach, 2013). In 2012, a law on higher education was adopted in Hungary to increase the time for training pedagogical staff up to 5 years according to the parallel model of training (The Teaching Profession in Europe Practices), which gives the opportunity to receive two specialties (Diakova, 2015). 
The results of an analysis of current approaches to reforming higher vocational education in Europe, the establishment of the European Qualifications Framework (2005) and the Single European Principles for Defining Pedagogical Competences and Qualifications (2006) encourage the consolidation of European and national institutions towards the formation of common standards for future professional education of teachers.

Since the 1960s, there has been a tendency to reduce the number of pedagogical colleges and increase the share of universities in teacher training. At the university college which provides general education and special training in the chosen field of knowledge, the student studies 3-4 years. Those wishing to obtain the profession of teacher can at the same time study at the Faculty of Education, where they study vocational and pedagogical courses and have pedagogical practice (Khomych, 2003).

The process of standardization of vocational training of future elementary school teachers in foreign countries has the following general tendencies: reduction of the share of pedagogical colleges and their accession to universities, their transformation into pedagogical faculties of universities; updating the content of psychological and pedagogical training, combining it with pedagogical practice; increase of the duration of studies in the pedagogical colleges; two-stage European Union training system: training for bachelor's and master's degrees.

At the same time, there are also differences in the process of teacher training: in the duration of the training, which ranges from 3 to 4 years in different countries; in the content of preparation of elementary school teachers, etc.

Such tendencies, we believe, are caused by the processes of globalization of economy, science and culture that are taking place in the modern world.

Thus, the analysis of the training of future teachers in foreign countries shows the modernization of the system of vocational training and the desire to consolidate efforts to formulate uniform standards for such training.

\section{Integration of pedagogical education of EU countries into the pan-European educational space}

The end of the XX - beginning of the XXI century was marked by the reform of the national systems of pedagogical education of the countries of the European Community, which is conditioned by the task of preparing the teacher for modern working conditions, who would be able to respond quickly to the needs of society, to adapt to innovative pedagogical processes.

The decisive factor in creating the concept of European education was the adoption by the Council of the European Community (May 24, 1988) and the Parliamentary Assembly of the Council of Europe (September 22, 1989) of special resolutions on the creation of a single European educational space. L. P. Pukhovska regards the pan-European space in education as "a common spiritual field, characterized by a set of shared value orientations, an invariant part of the content of education and modern pedagogical technologies that characterize the process of transferring the experience of previous generations to a generation of young Europeans (traditional learning) and the process of getting new experiences and promoting change in the existing culture (innovative learning)» (Pukhovska, 2007). According to the researchers of the reform of European pedagogical education (Avshenyuk, 2011), the concept of European education is built in such fundamental coordinates as multicultural, multi-ethnic and multilingual Europe.

The Resolution of the Council of Ministers of Education of the European Union (1988) defines five of the following principles for the development of a European educational space: a multicultural Europe (taking into account the diversity of national approaches in education and training; foreign language learning); a mobile Europe (mutual recognition of diplomas, exchange of pupils, students, teachers); a Europe of vocational training for all (equal access for all children to high quality education); a Europe of skills as a quality improvement of basic education (improvement of quality of basic education; improvement of the system of training of youth in accordance with the needs of 
the society development; improvement of basic training of pedagogical staff); a Europe that is open to the world (strengthening ties with other countries, working with international organizations).

The implementation of trans-European programs (Socrates, Tempus, Leonardo da Vinci, Europass, etc.) by France, the introduction of such special courses as "The European Space in Education" and "Our Europe» at the university teacher training institutes, the ratification of the Action Plan (2000) became an important condition for the formation of the European Higher Education Area (Lashchykhina, 2009).

Binytska (2013) highlighting the tendencies of the development of higher pedagogical schools in the 1990s and the beginning of the 20th century in the Republic of Poland, emphasizes the strengthening of international integration and cooperation with foreign higher educational establishments and the participation of Polish universities in European educational programs and exchange programs for students and academic staff.

The Greek Government promotes European and international dimensions in education, implemented as follows: "participation in the formulation and implementation of EU education programs and policies; participation in European and international organizations and their programs; national initiatives on bilateral and multilateral agreements in the field of education; promotion of European and international dimensions in all curricula at all levels of education; promoting the spread of the Greek language and expanding the teaching of Greek studies abroad» (Avshenyuk, 2011).

The basic principles of the Bologna Process are being introduced into the Greek elementary teacher training system, the introduction of the European component into the curricula and elementary teacher training programs (such courses as "New Europe Education», "European and International Space in Education», «European Integration as a Challenge for Education», «European educational programs», etc.) (Korotova, 2008).

The globalization processes and migration of citizens of different countries in Greece have made it necessary to organize multicultural education. The principle of multiculturalism in the education of Greece is realized through the development of new school programs and textbooks, the creation of special programs for the education of children of national minorities (foreigners, repatriates, gypsies and muslims), the existence of the Institute of Education of Compatriots and Intercultural Education, Centers for European Languages.

The creation of a European educational space does not mean the rejection of national peculiarities of the content of education and organization of the educational systems of each of the countries of the European community (Avshenyuk, 2011).

Researchers on the development of higher education in the member states of the Organization for Economic Co-operation and Development of the USA, Canada, Finland and Norway highlight such a tendency as the internationalization of higher education. «Internationalization in higher education at national, sectoral and institutional levels is understood to mean the process by which the aims, functions and organization of educational services take on an international dimension» (OECD, 2005).

The advantages of internationalization can be attributed to the emergence of international standards of quality and enhancement of innovation in higher education, the expansion of international cooperation, the activation of academic and student mobility.

The main instruments for supporting the migration of foreign specialists and talented students are the academic scholarship system. Austria, Finland, Hungary, Germany, the United Kingdom (for EU students), Ireland, Holland, Malta, Norway, Switzerland are most actively implementing this strategy.

In Germany, more than 200 DAAD (Deutscher Akademischer Austaush Dienst) programs are in operation in various countries in all scientific fields, supported by a number of government 
agencies and international organizations, including Alexander von Humboldt Foundation, Friedrich Burt Foundation, German Research Foundation and others.

The results of the internationalization of higher education in Poland were the growth of student mobility, the introduction of an ECTS-based credit system at certain universities, and the creation of an education quality assessment system. Poland has been active in the EU programs Tempus and Socrates. In particular, during the implementation of the Tempus program, 13,000 Polish students had the opportunity to study at EU universities, and within the Socrates program 12,253 Polish students studied abroad from 1998 to 2002 (OECD, 2005).

The development of internationalization of higher education is facilitated by the increased availability of the Internet, which allows to significantly expand international cooperation in the field of education (distance learning, virtual universities, etc.).

\section{Individualization of teaching of future teachers}

In the countries of the European community at the present stage there is a kind of conceptual reorientation in the preparation of future teachers: the main emphasis is placed on the formation and development of the teacher's personality, on the formation of his/her creative personality.

Within the humanistic approaches the idea of becoming a professional individual and professional self-development of teachers is actualized, the essence of which is that in the process of professional preparation of a student his/her theoretical, motivational, practical readiness for professional self-understanding and harmonious professional integration should be formed. This means choosing the best and most effective means of influence and interaction with the students for each teacher.

The ability to effectively combine these styles is seen as an organic component of the modern teacher's professional competence. The main focus in this context is on the communicative competence of the future teacher, the formation of which is carried out mainly in special seminars, trainings, project work, in the process of discussion.

\section{DISCUSSION}

\section{Forming the image of an effective teacher}

In the context of European integration, the personality of the teacher acquires new characteristics. As outlined in the Comprehensive European Principles on Teachers' Competences and Qualifications, the teaching profession should be: highly qualified; encouraging lifelong learning; mobile; a profession based on partnership.

These characteristics are interpreted by European experts as the core requirements for the profession of European teacher of the 21st century: a) high teacher qualification requirement (each teacher is required to have extensive subject knowledge, thorough pedagogical knowledge, skills and competencies to manage and support the learning process. He/she should understand the social and cultural dimensions of education); b) the requirement for a teacher to train throughout life (the need to continue their professional development throughout their teaching activities); c) requirement for the mobility of the teaching profession (support and promotion of teacher training in different European countries with a view to his/her further professional development); d) requirement for partnership as a basis of pedagogical profession (organization of work of educational institutions in partnership with schools, local authorities, various providers in the field of pedagogical education) (Avshenyuk, 2011).

A joint statement by the European Ministers of Education, signed in Bologna on 19 June 1999 (Bologna Declaration), stated that one of the top priorities for the creation of a European Higher Education Area was to promote mobility for free movement, in particular: for students, it is 
necessary to provide an opportunity to get education and practical training; for teachers, researchers and administrative staff, it is necessary to ensure recognition and credit for the time spent in research, teaching and internships in the European context (Bogoslovskyj, Pysareva, Triapitsyna, 2007).

Scientists identify the concept of international student mobility, which includes two streams: Asian students studying at universities in North America, Western Europe and Australia; mobility within the European Union within various student mobility support programs.

Academic mobility is an opportunity for students, teachers, administrative and management staff to move from one university to another in order to realize those opportunities that are not available in their university. It gives the student the opportunity to receive a versatile education in the chosen field of study, to learn the European culture, to nurture the feelings of a citizen of Europe (Bodnar, Mirkovich, Koval, 2019; Kvitka et al., 2019).

However, as European practice shows, this process has not yet become widespread. In Western Europe, academic student mobility is $5-10 \%$ of the total student population. In some countries, this indicator is better. In particular, in Finland, academic mobility programs cover $30 \%$ of students and the universities plan to bring it up to 50\% (Bogoslovskyj, Pysareva and Triapitsyna, 2007).

European scholars are working to substantiate the concept of European dimension in the 21st century, which should include the following components related to: a) information (teachers must have information on European integration: knowledge of the history, culture, language, education, etc. of the member states of the European community; knowledge of institutions, daily life, initiatives, European cultural heritage, the process of European cooperation, which things are common and different in European countries, etc.); b) awareness and identity (developing openminded teachers, respect for people in other countries, their culture, religion, etc.).

The development of the concept of a European dimension in teacher education will be facilitated by the discussion conducted by the European Network of Teacher Education Policies, entitled "A European Teacher: Who is he/she?» and during which the characteristic features of «European» teachers were highlighted. These include: a) European identity (the European teacher is characterized by certain values, which show that he/she is not only a national teacher, feels the national roots of his/her country, but belongs to the whole of Europe. Unity in diversity is a key element of the development of European identity); b) European knowledge (knowledge of the education system and regulatory policy in different countries of Europe (Koval, Pukala, 2017). The European teacher appreciates the education system of his/her country and sees its connection with the education of other European countries; is familiar with European history, its influence on modern European society); c) European citizenship (the teacher shows solidarity with the citizens of other European countries and shares with them the values of democracy, freedom, respect for human rights. The so-called "European Studies» should be started in the school curriculum, reflecting the dynamics of the development of European citizenship); d) European quality (comparability and transparency in the qualifications and diplomas of different European countries, which will help to eliminate obstacles to teacher mobility. An important step towards solving academic and qualification problems is the Bologna process) (Avshenyuk, 2011).

In Norway, the main qualities of an effective teacher are: «a unique combination of personal qualities and stable tendencies of reaction, which act as subjective prerequisites of professional in pedagogical activity; reflection, which is connected with the formation of outlook, life positions, the development of consciousness, differentiation of intellectual abilities and interests».

Moritz (2004) exploring the system of professional training of teachers in Poland, points to the need to train the teacher as a kind of leader of values (possessing didactic, educational, guardianship skills; ability to promote the full development of the personality of the student as well as his/her own one; ability to bring up a person dedicated to his/her motherland and ready to 
respect the Polish constitution, in the spirit of humanism, tolerance, freedom of thought, social justice and the right to work; the ability to cultivate the spirit of morality, democracy and friendship among students between peoples.

A professional teacher must possess not only a skill in demonstrating acquired knowledge and skills, but also in competencies in identifying a professional position (Koval, Polyezhayev, Bezkhlibna, 2018).

\section{Polyparadigmality of future teacher training}

A paradigmatic approach to the analysis of the Genesis of teacher training in Western Europe allowed Pukhovska (2007) to identify four paradigms that coexist in the educational systems of European countries: academic-traditional, technological, individual and research-oriented.

In training teachers, these paradigms interact. The leading direction of future teachers' professional training is determined by the values declared in a particular country.

\section{Pedagogical practice in the system of preparation of future elementary school teachers}

A special role in the process of teacher training is given to pedagogical practice. The pedagogical practice of future elementary school teachers is continuous. According to Pukhovska (2007), a partnership between the university and the school promotes the involvement of university teachers and professional teachers in working together to train future teachers, thereby ensuring a combination of theory and practice.

Pedagogical practice is divided into active and passive. Students have passive practice during their first year of study and the active practice during the second, the third, and the forth years of study.

In the training of pedagogical staff in the European country there is a tendency to intensify and increase the duration of pedagogical practice. Table 1 presents the duration of pedagogical practice in preparing teachers for elementary schools in different countries.

Table 1. Duration of pedagogical practice in the preparation of elementary school teachers in the countries of the European Community.

\begin{tabular}{cc}
\hline Country & Duration of pedagogical practice \\
\hline England & $18-32$ weeks \\
France & 23 weeks \\
Germany & $13-15$ weeks \\
Denmark & 5 months \\
Norway & 24 months \\
Poland & 15 months \\
\hline
\end{tabular}

In every country, pedagogical practice has its own peculiarities. In Greece, it was carried out in pedagogical academies under the sole curriculum developed by the Ministry of National Education and Religion of Greece, which provides the following types of pedagogical practice: observation practice, trial lessons and undergraduate practice. In the period of pedagogical practice, the observation of the organization of the educational process by experienced school teachers and teachers of pedagogical academies, the analysis of the lessons of teachers, teachers and classmates, independent conducting of lessons and their self-analysis are used. At university pedagogical departments of elementary education the types, forms and duration of carrying out pedagogical practice are determined by each department separately. Particular attention is paid to the education of a new type of thinking (Korotova, 2008). 
In the process of organizing pedagogical practice students are obliged to attend different types of schools: experimental, special, small; practice in a multicultural class. However, there is little time spent on teaching practice (in particular, at the Pedagogical Department of the University of Athens only $2.1 \%$ of the total amount of teaching time is spent on pedagogical practice).

In the UK, the purpose of teaching practice is to create conditions for students to acquire a sufficient amount of professional knowledge and skills, to understand the factors that affect the learning process, to provide opportunities to practically participate in the school educational process, to facilitate the entry of future teachers in the profession. Pedagogical practice of future primary school teachers in the UK is continuous (Pukhovska, 2007).

\section{CONCLUSION}

The trends highlighted by us are indicative of increased innovation in teacher training, which implies not only the creation and dissemination of innovation, but also changes in activity and thinking. The results of the analysis of foreign experience of the European community in the field of preparation of future primary school teachers provide the basis to draw the following conclusions: a) in the preparation of future primary school teachers, it is advisable to identify the basic pedagogical competences that they need to master and to indicate them in the personal qualification characteristics file; b) it is advisable to create educational complexes "pedagogical college - university," which will provide an opportunity for consistency and continuity in the preparation of primary school teachers; $c$ ) international cooperation in the field of higher education should be enhanced: mobility of students, teachers, educational programs; integration into the curriculum of international dimensions and educational standards; institutional partnership; d) content of the training of a professional teacher who is capable of continuous development needs to be updated; e) it is necessary to increase the duration of pedagogical practice as a primary school teacher is a multi-subject professional; establish close contact between a university and a school regarding the structure and content of pedagogical practice; to introduce different types of pedagogical practices.

Thus, taking into account the world tendencies in the development of higher pedagogical education, experience of professional training of future teachers in the countries of the European community will help to improve the training of elementary school teachers in Ukrainian universities, to fulfill the requirements of the Bologna Declaration.

Further research is required for the content of vocational training, forms of mobility for students of pedagogical specialties, the formation of common standards for the training of future teachers and others.

Authors' Contributions: Onyshkiv, Z.: conception and design, acquisition of data, analysis and interpretation of data, drafting the article, critical review of important intellectual content; Kodliuk, Y.: conception and design, acquisition of data, analysis and interpretation of data, drafting the article, critical review of important intellectual content; Lesina, T.: conception and design, acquisition of data, analysis and interpretation of data, drafting the article, critical review of important intellectual content; Malyna, O.: conception and design, acquisition of data, analysis and interpretation of data, drafting the article, critical review of important intellectual content; Kichuk, N.: conception and design, acquisition of data, analysis and interpretation of data, drafting the article, critical review of important intellectual content. All authors have read and approved the final version of the manuscript.

Ethics Approval: Not applicable.

Acknowledgments: Not applicable. 


\section{REFERENCES}

Arsawan, I. W. E., Koval, V., Rajiani, I., Rustiarini, N. W., Supartha, W. G. and Suryantini, N. P. S. (2020). Leveraging knowledge sharing and innovation culture into SMEs sustainable competitive advantage. International Journal of Productivity and Performance Management, (in press). https://doi.org/10.1108/IJPPM-04-2020-0192

Association of Rectors of Pedagogical Universities in Europe (2019). Pedagogical Constitution of Europe. http://www.arpue.org/ index.php

Avshenyuk, N. M. (2011). Modernization of pedagogical education in European and Euro-Atlantic educational area. Kyiv, Pedahohichna dumka.

Bantash, A., Koval, V., Bashynska, M., \& Kozlovtseva, V. (2020). Balanced territorial economic development in the conditions of providing stability of human resources management. Economics. Ecology. Socium, 4(3), 58-66.

Binytska, K. M. (2013). Development of Higher Pedagogical Schools in the Republic of Poland (second half of XX beginning of XXI century). Khmelnytskyi.

Bodnar, S., Mirkovich, I., Koval, V. (2019). Human capital development in Ukrainian education system by means of language integrated teaching. Dilemas contemporaneos-educacion politica y valores, 7(SI), 14.

Bogoslovskyj, V. Y., Pysareva, S. A., Triapitsyna, A. P. (2007). Academic mobility: implementation in the Bologna process. Sankt-Peterburh.

Borkach, E. (2013). The Bologna Reform of Teacher Education in Ukraine and Hungary: A Comparative Analysis. American Journal of Educational Research, 1(11), 528-533.

Brito, R. S., Prado, J. R., \& Nunes, C. P. (2017). As condições de trabalho docente e o pós-estado de bem-estar social. Revista Tempos e Espaços em Educação, 10(23), 165-174. https://doi.org/10.20952/revtee.v10i23.6676

Diakova, T. A. (2015). Higher education in Hungary. Vestnyk VHU. Seryia: Problemy vyssheho obrazovanyia. 1,111-114.

Drobnic, J. (2019). The key innovations in career guidance on labour market. Economics Ecology Socium, 3(2), 12-22. https://doi.org/10.31520/2616-7107/2019.3.2-2

Khomych, L. O. (2003). Reforming the vocational training of elementary school teachers abroad. Pedahohichni nauky, 34, 202-209.

Korotova, Yu. M. (2008).Vocational training of elementary school teachers in modern Greece. Kharkiv.

Koval, V., \& Pukala, R. (2017). Implementation of regulatory policy in economic activity: development of the institute regulatory impact assessment. Economics Ecology Socium, 1(1), 24-32.

Koval, V., Polyezhayev, Y., \& Bezkhlibna, A. (2018). Communicative competences in enhancing of regional competitiveness in the labour market. Baltic Journal of Economic Studies, 4(5), 105-113.

Kvitka, S., Starushenko, G., Koval, V., Deforzh, H., \& Prokopenko, O. (2019). Marketing of Ukrainian higher educational institutions representation based on modeling of Webometrics Ranking. Marketing and Management of Innovations, 3, 60-72. http://doi.org/10.21272/mmi.2019.3-05

Lashchykhina, V.P. (2009). Development of the system of teacher training in France (second half of XX - beginning of XXI century). Kyiv.

Luchaninova, O., Koval, V., Deforzh, H., Nakonechna, L. \& Golovnia, O. (2019). Formation of communicative competence of future specialists by means of group work. Espacios, 40(41), 11.

Margvelashvili, I., \& Kostava, M. (2020). Improving financial education strategy for sustainable development. Economics. Ecology. Socium, 4(3), 1-11. https://doi.org/10.31520/2616-7107/2020.4.3-1

Moritz, Ya. (2004). The system of teacher training and ways of its optimization in the conditions of development of modern education in Poland). Kyiv.

Mushynska, N. (2018). Means of future economists' professional self-development in the educational process of foreign language studying. Economics, Ecology, Socium, 2(3), 45-56. https://doi.org/10.31520/2616-7107/2018.2.3-5

OECD (2005). Important issues of the development of education in OECD countries. Moskva.

Polishchuk, L. P. (2011). Professional training of primary school teachers in England in the context of European integration). Zhytomyr.

Pukhovska, L. P. (2007). Teacher Training in Western Europe: Things in Common and Differences. Kyiv: Vyshcha shkola. 
Roliak, A. O. (2020). Professional education of teachers in physical training and health: the experience of Denmark. Pedagogy of physical culture and sports, 24(3).

Silva, L. R., Santos, A. R., \& Santos, I. T. R. (2020). Public policies for education of/in the field and the school environment in a settlement of the MST: the intimate relationship with the pedagogical policy. Journal of Research and Knowledge Spreading, 1(1), e11737.

Sbruieva, A. A. (1999). Comparative pedagogy. Sumy: Redaktsiino-vydavnychyi viddil SDPU.

Received: 11 March 2021 | Accepted: 22 February 2021 | Published: 1 May 2021

This is an Open Access article distributed under the terms of the Creative Commons Attribution License, which permits unrestricted use, distribution, and reproduction in any medium, provided the original work is properly cited. 